BBA 73036

\title{
Effects of phospholipase A and pre-phospholipase A on black phospholipid membranes
}

The formation of black lipid membranes has been extensively investigated during the past few years ${ }^{1-9}$. Several studies included the effects of various proteins on these membranes ${ }^{10-14}$. If protein molecules come in close contact with lipid membranes and modify their structure, they must fit in the pattern of polar groups at the membrane surface. Phospholipases are of interest in this respect. They are highly specific and active on phosphoglyceride dispersions in water. Phospholipase A (EC 3.r.r.4), which catalyses exclusively the hydrolysis of the fatty acid ester linkage at the $\mathrm{C}-2$ position of phosphoglycerides, and an enzymatically inactive "precursor" (pre-phospholipase A) were used in the present work. To avoid membrane rupture by the action of the enzyme, particular phospholipids which are not degraded enzymatically, or the inactive form of the enzyme can be used.

Membranes were formed from 0.3 to $0.5 \%(\mathrm{w} / \mathrm{v})$ solutions of the phospholipids in $n$-decane. In some cases small amounts of ethanol were added. The phospholipids were synthesized according to established procedures ${ }^{15,16}$ and were homogeneous by thin-layer chromatography. The methods of membrane formation, resistance and capacitance measurements have been described previously ${ }^{7}, 17$.

Pure phospholipase A (mol. wt. $13800 \pm 500$ ) and pre-phospholipase A (containing 7 more amino acids) were isolated from porcine pancreas ${ }^{18}$. They are globular proteins and contain 7 disulfide bridges per molecule. The preparations proved to be homogeneous on disc electrophoresis over a wide $\mathrm{pH}$ range $\mathrm{e}^{\mathbf{1 8}}$. The pre-phospholipase $\mathrm{A}$ preparation contained some residual enzymatic activity (about $0.1 \%$ of full activity attained after release of the heptapeptide by trypsin).

Black films were prepared from the synthetic lecithins viz.: I,2-dipalmitoylsn-glycero-3-phosphoryl choline (I), I-stearoyl-2-myristoyl-sn-glycero-3-phosphoryl choline (II), and I-oleoyl-2-stearoyl-sn-glycero-3-phosphoryl choline (III) and from 2 lecithin analogues, in which the only modification was the replacement of the ester bond at the $\mathrm{C}-2$ position by an ether or a carbon-carbon bond, viz.: rac-I-oleoyl2-O-palmityl-sn-glycero-3-phosphoryl choline (IV) and $r a c$-I-oleoyl-2- $n$-hexadecylpropanediol-3-phosphoryl choline (V). Compounds IV and $V$ are not degraded by phospholipase A. The lifetimes of membranes from the fully saturated lecithins (I, II) have been significantly shorter than those prepared from the other phospholipids (III, IV and V). Electrical resistance and capacitance of black films of these phospholipids ( $\mathrm{I}-\mathrm{V}$ ) in aqueous solutions of $\mathrm{IO}^{-\mathbf{2}} \mathrm{M} \mathrm{KCl}, \mathrm{CaCl}_{2}$ and $\mathrm{KI}$ were similar (Table I).

With the normal lecithins it proved to be impossible to obtain black membranes. both in phospholipase $\mathrm{A}$ and in pre-phospholipase $\mathrm{A}$ solutions. This was attributed to hydrolysis of lecithin to the I-acyl-lysolecithin which is known to make black films. unstable above a certain concentration.

Black membranes of good stability could be formed with both lecithin analogues in $2 \cdot \mathrm{IO}^{-6} \mathrm{M}$ and $\mathrm{IO}^{-5} \mathrm{M}$ solutions of pre-phospholipase $\mathrm{A}$, and in $2 \cdot \mathrm{IO}^{-6} \mathrm{M}$ solutions of phospholipase $\mathrm{A}$. In $\mathrm{I}^{-5} \mathrm{M}$ solution of active enzyme, the stability of membranes. was decreased. The electrical resistance of the black membranes was lowered by a factor IOO-IOOO in the solutions of $\mathrm{IO}^{-5} \mathrm{M}$ phospholipase $\mathrm{A}$ and pre-phospholipase $\mathrm{A}$ 
TABLE I

PROPERTIES OF BLACK MEMBRANES OF SYNTHETIC LECITHINS

Membranes from dipalmitoyllecithin were formed at $50^{\circ}$, all other membranes at $37^{\circ}$. All values are the mean of at least 3 membranes.

\begin{tabular}{|c|c|c|c|c|c|}
\hline \multirow[t]{2}{*}{ Lecithins and analogues } & \multicolumn{3}{|c|}{ Resistance $\left(\Omega \cdot \mathrm{cm}^{2}\right)$} & \multicolumn{2}{|c|}{ Capacitance $\left(\mu F / \mathrm{cm}^{2}\right)$} \\
\hline & $\mathrm{IO}^{-2} \mathrm{MKCl}$ & $\mathrm{IO}^{-2} \mathrm{M} \mathrm{CaCl}_{2}$ & $I O^{-2} M K I$ & $\mathrm{IO}^{-1} \mathrm{MKCl}$ & $\mathrm{IO}^{-\mathbf{2}} \mathrm{MCaCl}$ \\
\hline $\begin{array}{l}\text { (Dipalmitoyl)- } \\
\text { lecithin (I) }\end{array}$ & $0.5 \cdot 10^{8}$ & $0.3 \cdot 10^{8}$ & $0.6 \cdot 10^{4}$ & $0.34 \pm 0.03$ & 一 \\
\hline $\begin{array}{l}\text { (Stearoyl-myristoyl)- } \\
\text { lecithin (II) }\end{array}$ & $0.9 \cdot 10^{8}$ & $I . I \cdot 10^{8}$ & $1.2 \cdot 10^{4}$ & $0.32 \pm 0.02$ & 一 \\
\hline $\begin{array}{c}\text { (Oleoyl-stearoyl)- } \\
\text { lecithin (III) }\end{array}$ & I.I $\cdot 10^{8}$ & $\mathrm{I} . \mathrm{O} \cdot 1 \mathrm{O}^{8}$ & $\mathrm{I} .7 \cdot 1 \mathrm{O}^{4}$ & - & $0.35 \pm 0.02$ \\
\hline Compound IV & $6.0 \cdot 10^{8}$ & $\mathrm{I} .5 \cdot 1 \mathrm{O}^{8}$ & $3.4 \cdot \mathrm{IO}^{4}$ & - & $0.34 \pm 0.02$ \\
\hline Compound V & $4 \cdot 4 \cdot 10^{8}$ & $\mathrm{I} .8 \cdot 1 \mathrm{O}^{8}$ & $2.9 \cdot \mathrm{IO}^{4}$ & - & $0.35 \pm 0.02$ \\
\hline
\end{tabular}

\section{TABLE II}

EFFECTS OF PURE PHOSPHOLIPASE A AND PRE-PHOSPHOLIPASE A ON BLACK MEMBRANES OF LECITHIN ANALOGUES

Phospholipase A and pre-phospholipase A were dissolved in $\mathrm{IO}^{-2} \mathrm{M} \mathrm{CaCl}_{2}$.

\begin{tabular}{|c|c|c|c|c|c|c|}
\hline & \multicolumn{3}{|c|}{ Pre-phospholipase A } & \multicolumn{3}{|c|}{ Phospholipase $A$} \\
\hline & \multicolumn{2}{|l|}{$\begin{array}{l}\text { Resistance } \\
\left(\Omega \cdot \mathrm{cm}^{2}\right)\end{array}$} & \multirow{2}{*}{$\begin{array}{l}\text { Capacitance } \\
\left(\mu F / \mathrm{cm}^{2}\right) \\
\mathrm{IO}^{-5} \mathrm{M}\end{array}$} & \multicolumn{2}{|l|}{$\begin{array}{l}\text { Resistance } \\
\left(\Omega \cdot \mathrm{cm}^{2}\right)\end{array}$} & \multirow{2}{*}{$\begin{array}{l}\text { Capacitance } \\
\left(\mu F / \mathrm{cm}^{2}\right) \\
2 \cdot \mathrm{IO}^{-6} \mathrm{M}\end{array}$} \\
\hline & $2 \cdot I O^{-6} M$ & $I O^{-5} M$ & & $2 \cdot I O^{-6} M$ & $I O^{-5} M$ & \\
\hline Compound IV & $3 \cdot 10^{8}$ & $2 \cdot 10^{5}$ & $0.33 \pm 0.02$ & $4 \cdot 10^{6}$ & $7 \cdot 10^{4}$ & $0.32 \pm 0.02$ \\
\hline Compound V & $5 \cdot 10^{8}$ & $I \cdot I O^{6}$ & $0.34 \pm 0.02$ & $9 \cdot 10^{7}$ & $9 \cdot 10^{4}$ & $0.33 \pm 0.02$ \\
\hline
\end{tabular}

(Table II) when compared with the value recorded in $\mathrm{IO}^{-2} \mathrm{M} \mathrm{CaCl}_{2}$ in the absence of protein (Table I). Only a small difference was observed in $2 \cdot \mathrm{IO}^{-6} \mathrm{M}$ solutions of phospholipase A, while in solutions of pre-phospholipase $A$ at this concentration, the resistance was practically identical to that in $\mathrm{a} \mathrm{CaCl}_{2}$ solution without protein. The resistance of membranes in the protein solutions varied over a greater range than usual for individual membranes in electrolyte solutions. With protein, variations of a factor I00-200 have been observed. The low resistance in the protein solutions was observed only when the membrane reached the black state. In the early state, as long as a thick lamella was present, the resistance was high. This may indicate that the low resistance was a property of the black area and not caused by border leakage. No significant differences in capacitance between membranes with or without proteins were detected (Table II).

It may be concluded that phospholipase $\mathrm{A}$ and pre-phospholipase $\mathrm{A}$ are primarily adsorbed to the polar region on the membrane surface. The decrease of the electric resistance may be caused by an alteration of the molecular arrangement of the 
phospholipids due to an interaction either, of their polar groups or their apolar residues with the protein. The observation of nearly identical values in capacitance of membranes with and without protein does not argue against an adsorption on the membrane surface (the capacitance of a membrane covered on either side with a monomolecular layer of protein would be only a few percent smaller than that of the hydrocarbon core alone), but it indicates that a massive penetration of protein molecules into the hydrocarbon core of the membrane did not occur. However, a relatively small number of polar pores created by protein molecules traversing the apolar barrier and which occupy a very small part of the membrane only, could account for the observed decrease in resistance (this can be verified by a rough calculation on the basis of a simple model). At present it is not possible to decide whether the observed effects are due to adsorption of protein molecules on the polar surface of the lipid membrane, or whether they are caused by a small number of protein molecules which penetrated into the hydrocarbon region.

The authors wish to thank Dr. P. LÄUGER for helpful discussions and Dr. H. J. EIBL for the gift of dipalmitoyllecithin.

Department of Biochemistry,

W. LesslaUER ${ }^{\star}$

University of Utrecht,

A. J. Slotboom

Utrecht (The Netherlands)

N. M. Postema

G. H. DE HAAS

L. L. M. VAN DeEnen

I P. Mueller, D. O. Rudin and W. C. Westcott, Nature, I94 (I962) 979.

2 C. Huang, L. Wheeldon and T. E. Thompson, J. Mol. Biol., 8 (I964) I 48.

3 T. Hanai, D. A. Haydon and J. Taylor, Proc. Roy. Soc. London, Ser. A, 281 (1964) 377.

4 A. V. Babakov, L. N. Ermishinin and A. Liberman, Natuve, 2 io (Ig66) 953.

5 H. T. TIEn AND E. A. Dawidowicz, J. Colloid Interface Sci., 22 (I966) 438.

6 H. Van Zutphen, L. L. M. Van Deenen and S. C. Kinsky, Biochem. Biophys. Res. Commun., 22 (I966) 393 .

7 P. Läuger, W. Lesslater, E. Marti and J. Richter, Biochim. Biophys, Acta, I 35 (I967) 20.

8 T. E. Andreolli, J. A. Bangham and D. C. Tosteson, J. Gen. Physiol., 50 (I967) I 729.

9 H. J. VReeman, Koninkl. Ned. Akad. Wetenschap., Ser. B, 69 (1966) 542.

io T. Hanai, D. A. Haydon and J. Taylor, J. Theoret. Biol., 9 (I965) 422.

I I A. H. Maddy, C. Huang and T. E. Thompson, Federation Proc,, 25 (1966) 933.

I2 P. Mueller and D. O. Rudin, Nature, 2 I 3 (I967) 603.

I 3 A. Cass and A. Finkelstein, J. Gen. Physiol., 5o (ig67) I 765.

I 4 L. M. Tsofina, E. A. Liberman and A. V. Babakov, Nature, 2 I 2 (I966) 68I.

I 5 L. L. M. Van Deenen and G. H. De HaAs, Advan. Lipid Res., 2 (1964) i67.

I6 G. H. De HaAs and L. L. M. Van Deenen, Tetrahedron Letters, (I960) 7.

17 W. Lesslauer, J. Richter and P. LÄUger, Nature, 2 I 3 (Ig67) I 224.

i 8 G. H. De Haas, N. M. Postema, W. Nieuwenhuizen and L. L. M. Van Deenen, Biochim. Biophys. Acta, in the press.

Received December $4^{\text {th, }}$ 1967

* Present address: Institute of Physical Chemistry, University of Basel, Basel, Switzerland.

Biochim. Biophys. Acta, I 50 (r968) 306-308 